\title{
Exhaled nitric oxide, nitrite/nitrate levels, allergy, rhinitis and asthma in the EGEA study
}

\author{
Rachel Nadif ${ }^{1,2}$, Marta Rava ${ }^{1,2}$, Brigitte Decoster ${ }^{3}$, Hélène Huyvaert ${ }^{3,4}$, \\ Nicole Le Moual ${ }^{1,2}$, Jean Bousquet ${ }^{1,2,5}$, Valérie Siroux ${ }^{6,7,8}$, Raphaëlle Varraso ${ }^{1,2}$, \\ Isabelle Pin ${ }^{6,7,8}$, Farid Zerimech ${ }^{4}$ and Régis Matran ${ }^{3}$
}

\begin{abstract}
Affiliations: 'INSERM, U1018, CESP Centre for Research in Epidemiology and Population Health, Respiratory and Environmental Epidemiology Team, Villejuif, France. ${ }^{2}$ Univ. Paris-Sud, UMRS 1018, Villejuif, France. ${ }^{3}$ Univ. Lille Nord de France, Lille, France. “Laboratoire de Biochimie, Centre de Biologie Pathologie, CHRU de Lille, Lille, France. ${ }^{5} \mathrm{CHU}$ Arnaud de Villeneuve, Montpellier, France. ${ }^{6}$ Université Grenoble Alpes, Institut Albert Bonniot, Team of Environmental Epidemiology Applied to Reproduction and Respiratory Health, Grenoble, France. ${ }^{7}$ INSERM, Institut Albert Bonniot, Team of Environmental Epidemiology Applied to Reproduction and Respiratory Health, Grenoble, France. ${ }^{8} \mathrm{CHU}$ de Grenoble, Institut Albert Bonniot, Team of Environmental Epidemiology Applied to Reproduction and Respiratory Health, Grenoble, France.
\end{abstract}

Correspondence: Marta Rava, Genetic and Molecular Epidemiology Group, Human Cancer Genetics Program, Spanish National Cancer Research Centre - Centro Nacional de Investigaciones Oncológicas (CNIO), Melchor Fernández Almagro, 3, 28029-Madrid, Spain. E-mail: mrava@cnio.es

ABSTRACT Although interest in biomarkers in the nitrate-nitrite-NO pathway has recently increased, associations between nitrite $\left(\mathrm{NO}_{2}^{-}\right)$and nitrate $\left(\mathrm{NO}_{3}^{-}\right)$, and asthma, allergic sensitisation and rhinitis remain unclear. The study aimed to evaluate the associations between $\mathrm{NO}_{2}{ }^{-} / \mathrm{NO}_{3}{ }^{-}$and exhaled fraction of nitric oxide ( $\mathrm{FeNO}$ ) levels with asthma, allergic sensitisation and rhinitis.

Plasma and exhaled breath condensate (EBC) $\mathrm{NO}_{2}{ }^{-} / \mathrm{NO}_{3}{ }^{-}$and $\mathrm{FeNO}$ levels were measured in 523 adults of the French Epidemiological study on Genetics and Environment of Asthma. Allergic sensitisation was defined by a positive skin prick test for at least one aeroallergen. Subjects were classified as non-sensitised, sensitised and as having allergic rhinitis.

Plasma $\mathrm{NO}_{2}{ }^{-} / \mathrm{NO}_{3}{ }^{-}$level was unrelated to any disease phenotypes. $\mathrm{EBC} \mathrm{NO}_{2}{ }^{-} / \mathrm{NO}_{3}{ }^{-}$level was unrelated to any asthma phenotypes. EBC $\mathrm{NO}_{2}{ }^{-} / \mathrm{NO}_{3}{ }^{-}$and $\mathrm{FeNO}$ levels were correlated in sensitised subjects only $(\mathrm{r}=0.21 \pm 0.10, \mathrm{p}=0.01) . \mathrm{EBC} \mathrm{NO}_{2}{ }^{-} / \mathrm{NO}_{3}{ }^{-}$and $\mathrm{FeNO}$ levels were higher in sensitised than in non-sensitised subjects (adjusted geometric mean (95\% CI): 2.36 (1.96-2.84) versus 1.72 (1.38-2.14) $\mu \mathrm{mol}$ per mg proteins, $\mathrm{p}=0.008$; and $18.3(16.7-20.0)$ versus $14.8(13.3-16.5) \mathrm{ppb}, \mathrm{p}=0.0006$, respectively), with gradual relationships from sensitised subjects to those with allergic rhinitis $(\mathrm{p}<0.0001)$.

Results suggest that $\mathrm{EBC} \mathrm{NO}_{2}{ }^{-} / \mathrm{NO}_{3}{ }^{-}$and $\mathrm{FeNO}$ levels may be considered as biological markers of intensity of allergic sensitisation and rhinitis.

○ @ERSpublications

The EGEA study: exhaled nitrate/nitrite/NO levels may be considered markers for intensity of allergy and rhinitis http://ow.ly/uKbxh

This article has supplementary material available from erj.ersjournals.com

Received: Nov 192013 | Accepted after revision: Feb 282014 | First published online: May 22014

Support statement: Research funded in part by PHRC-Paris, PHRC-Grenoble, ANR 05-SEST-020-02/05-9-97, ANR-06CEBS, ANR-CES-2009, Region Nord Pas-de-Calais, Merck Sharp and Dohme (MSD), and the GA2LEN project, Global Allergy and Asthma European Network.

Conflict of interest: Disclosures can be found alongside the online version of this article at erj.ersjournals.com

Copyright @ERS 2014 


\section{Introduction}

The interest in measuring biological markers in exhaled breath condensate (EBC) in epidemiological studies of respiratory diseases has increased in the past years. Among the pathways involved in the pathophysiology of asthma, the metabolism of nitric oxide (NO), also called the nitrate-nitrite-NO pathway has taken a growing place in this research field [1]. NO metabolism is complex, and both NO measured by the exhaled fraction of $\mathrm{NO}(\mathrm{FeNO})$ and $\mathrm{NO}$-related compounds such as nitrites $\left(\mathrm{NO}_{2}{ }^{-}\right)$and nitrates $\left(\mathrm{NO}_{3}{ }^{-}\right)$are relevant biological markers that may help to better understand the pathophysiology of asthma and allergy [2].

FeNO is the most studied of these, and it is commonly considered as a noninvasive indirect marker of airway inflammation [3]. Both epidemiological and clinical studies have shown increased level of FeNO in children and adults with asthma, and positive associations between FeNO and allergic sensitisation are consistent over the studies, regardless of rhinitis or asthma [4]. Studies on associations between $\mathrm{NO}_{2}{ }^{-}$and $\mathrm{NO}_{3}{ }^{-}$levels with asthma, allergy or rhinitis have led to more conflicting results both in adults and children [5-17]. Until now, none of these studies has simultaneously performed measurements of $\mathrm{EBC} \mathrm{NO}_{2}{ }^{-} / \mathrm{NO}_{3}{ }^{-}$and $F \mathrm{eNO}$ levels in the same subjects. Recently, in a large number of adults from the French Epidemiological study on Genetics and Environment of Asthma (EGEA), $\mathrm{EBC} \mathrm{NO}{ }_{2}{ }^{-} / \mathrm{NO}_{3}{ }^{-}$and $\mathrm{FeNO}$ levels were found to be correlated in subjects without asthma [18].

Nitric oxide has different functions and roles in pathophysiology, which may be better explained by considering its compartmentalised production [19]. In this study, we compared the association between total $\mathrm{NO}_{2}{ }^{-} / \mathrm{NO}_{3}{ }^{-}$levels measured in two compartments (plasma and $\mathrm{EBC}$ ) and FeNO levels with asthma, allergic sensitisation and rhinitis among 523 adults from the EGEA study. We hypothesised that the associations will be different depending on the compartments, biomarkers and outcomes studied.

\section{Methods}

Study design

Data used for the analyses were collected in the framework of the 12-year follow-up of EGEA. EGEA is a French cohort study based on an initial group of asthma cases and their first-degree relatives, and controls (first survey, $\mathrm{n}=2047$; https://egeanet.vjf.inserm.fr/). The protocol and descriptive characteristics have been described previously [20, 21]. A follow-up of the initial cohort was conducted between 2003 and 2007 [22]. Among the alive cohort $(n=2002), 92 \%(n=1845)$ completed a short, self-administered questionnaire and among them 1601 had a complete examination. All subjects responded to a questionnaire based on international standardised tools to diagnose asthma and to determine respiratory and allergic symptoms, treatments, and environmental exposures. The present cross-sectional analysis includes those who were adults at the second survey ( $\geqslant 16$ years old, $n=1570$ adults) with available data on asthma, current rhinitis, allergic sensitisation, and available measurements of $\mathrm{EBC} \mathrm{NO}_{2}{ }^{-} / \mathrm{NO}_{3}{ }^{-}$and FeNO levels $(\mathrm{n}=523)$. Subjects included in the analyses were younger, more often reported ever asthma and current rhinitis, and had higher levels of $\mathrm{NO}_{2}{ }^{-} / \mathrm{NO}_{3}{ }^{-}$and immunoglobulin $\mathrm{E}$ (IgE) than those not included in the analyses $(\mathrm{n}=1047)$. The two groups were similar for sex, smoking, current asthma status, allergic sensitisation, lung function tests, and eosinophil count (table S1 in supplementary data).

Ethical approval was obtained from the relevant institutional review board committees (Cochin Port-Royal Hospital and Necker-Enfants Malades Hospital, Paris, France). Written informed consent was signed by all participants.

\section{Respiratory phenotypes}

Subjects with ever asthma were defined by a positive answer to either: "Have you ever had attacks of breathlessness at rest with wheezing?", or "Have you ever had asthma attacks?", or if they were recruited as asthmatic cases at the first survey.

Allergic sensitisation was defined by a positive skin prick test (SPT+) with a mean wheal diameter $\geqslant 3 \mathrm{~mm}$ than the negative control for at least one of 12 aeroallergens (indoor: cat, Dermatophagoides pteronyssinus, Blattela germanica; outdoor: olive, birch, Parieteria judaica, timothy grass, Cupressus and ragweed pollen; and moulds: Aspergillus, Cladosporium herbarum and Alternaria tenuis). Subjects were classified as sensitised if they have one or more SPT+. Current rhinitis was defined by a positive answer to one of the two questions: "Have you ever had rhinitis?" or "Have you ever had hay fever?" and a positive answer to "have you had sneezing problems or a runny nose in the past 12 months?" Allergic rhinitis was defined as having both current rhinitis and one or more SPT+. Subjects were also classified in three groups as non-sensitised (no SPT+), sensitised only (having one or more SPT+ and no current rhinitis) and as having allergic rhinitis (one or more SPT+ and current rhinitis).

Eosinophilia was defined as eosinophil count $\geqslant 5 \%$. Details on other phenotypes are given in supplementary data. 


\section{Biological phenotypes}

EBC was collected with an RTube ${ }^{\mathrm{TM}}$ (Respiratory Research Inc., Charlottesville, VA, USA) according to a standardised method. Briefly, the RTube was rinsed with deionised water and dried thoroughly. Participants breathed orally at tidal volumes into a mouthpiece attached to a cold condenser $\left(-20^{\circ} \mathrm{C}\right)$. They were seated comfortably with a headrest. All headrests and back seats were tilted slightly to avoid any saliva contamination during breathing manoeuvres (see supplementary data for more details).

Total nitrite-nitrate $\left(\mathrm{NO}_{2}{ }^{-} / \mathrm{NO}_{3}{ }^{-}\right)$levels were measured in plasma and $\mathrm{EBC}$ as previously described [23]. All measurements were done in duplicate. Analytical intra-run imprecision was below 3\%. Measurements with a coefficient of variation $>15 \%$ and extreme outliers $(n=7)$ were excluded from the analyses (see supplementary data for more details).

Measurements of FeNO were realised before other pulmonary function tests according to American Thoracic Society/European Respiratory Society recommendations (see supplementary data). The measurement was performed only in three of the five centres involved in the EGEA study, which explained in a large part the attrition on numbers of subjects included in the analysis compared to the total number. FeNO level was measured at $50 \mathrm{~mL} \cdot \mathrm{s}^{-1}$ flow rate as previously described [22].

\section{Statistical methods}

Joint distribution of asthma, SPT+ and current rhinitis was shown with a Venn diagram (fig. 1). Total plasma and $\mathrm{EBC} \mathrm{NO}_{2}{ }^{-} / \mathrm{NO}_{3}{ }^{-}$and $\mathrm{FeNO}$ levels were $\log _{10}$-transformed as a result of their skewed distribution.

Also as part of the EGEA study, we previously reported that plasma $\mathrm{NO}_{2}{ }^{-} / \mathrm{NO}_{3}{ }^{-}$level was increased with leafy vegetable consumption and decreased in smokers and with storage time, that $\mathrm{EBC} \mathrm{NO}_{2}{ }^{-} / \mathrm{NO}_{3}{ }^{-}$level was decreased in smokers and with exposure to ambient ozone concentration [23], and that FeNO level was associated with season of examination [22]. Furthermore, storage time and season of examination varied with centre. Therefore, estimates were adjusted for: 1) age, sex, smoking, leafy vegetable consumption and centre for plasma $\left.\mathrm{NO}_{2}{ }^{-} / \mathrm{NO}_{3}{ }^{-} ; 2\right)$ age, sex, smoking, ambient ozone concentration and centre for $\mathrm{EBC}^{-} \mathrm{NO}_{2}{ }^{-}$ $\mathrm{NO}_{3}{ }^{-}$; and 3) age, sex, height, smoking and centre for FeNO. Since the ratio of higher oxides of nitrogen $\left(\mathrm{NO}_{\mathrm{x}}\right.$, including $\mathrm{NO}_{2}{ }^{-}$and $\left.\mathrm{NO}_{3}{ }^{-}\right)$to $\mathrm{NO}$ was reported to be more informative than each measurement alone by NGUYEN et al. [13], the $\left(\mathrm{NO}_{2}{ }^{-}+\mathrm{NO}_{3}{ }^{-}\right) / \mathrm{NO}$ ratio $\left(\mathrm{NO}_{\mathrm{x}} / \mathrm{NO}\right.$ ratio) has also been studied.

As inhaled corticosteroids (ICS) use can decrease FeNO levels, and as $\mathrm{NO}_{2}{ }^{-} / \mathrm{NO}_{3}{ }^{-}$and $\mathrm{FeNO}$ are biological markers involved in the same pathway, association between ICS use and $\mathrm{EBC} \mathrm{NO}_{2}{ }^{-} / \mathrm{NO}_{3}{ }^{-}$level was studied. Since increased body mass index (BMI)/obesity has been associated with lower FeNO level, estimates were also adjusted for BMI as a sensitivity analysis.

Associations between total $\mathrm{NO}_{2}{ }^{-} / \mathrm{NO}_{3}{ }^{-}$levels, FeNO levels, and the $\mathrm{NO}_{\mathrm{x}}$ ratio $\left(\mathrm{NO}_{2}{ }^{-}+\mathrm{NO}_{3}{ }^{-}\right) / \mathrm{NO}$ and asthma phenotypes, allergic sensitisation and current rhinitis were estimated with linear regression models. Parameter estimates were assessed by using generalised estimating equations (GEEs), with an exchangeable working correlation to account for the potential clustering within families (SAS MIXED procedure). The level of statistical significance was set at $\alpha=0.05$. Two-sided $p$-values were reported for all association estimates. All analyses were conducted using SAS software, version 9.3 (SAS Institute, Inc., Cary, NC, USA).

FIGURE 1 Concordance of ever asthma, allergic sensitisation (positive skin prick test, SPT+) and current rhinitis (proportional Venn diagram). Data on current rhinitis was missing for four participants without allergic sensitisation and asthma, one participant with asthma and one participant with allergic sensitisation $(n=517)$.

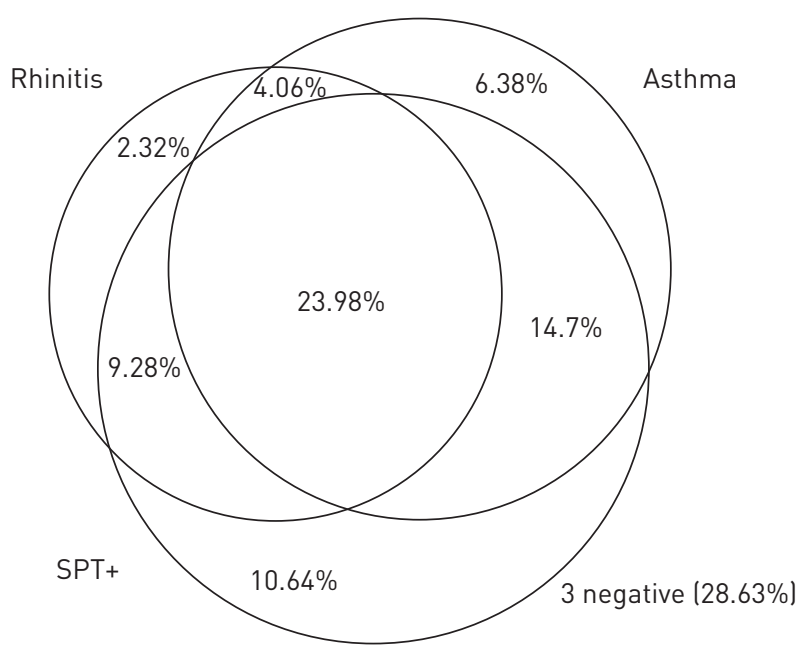


TABLE 1 Characteristics of subjects according to asthma status

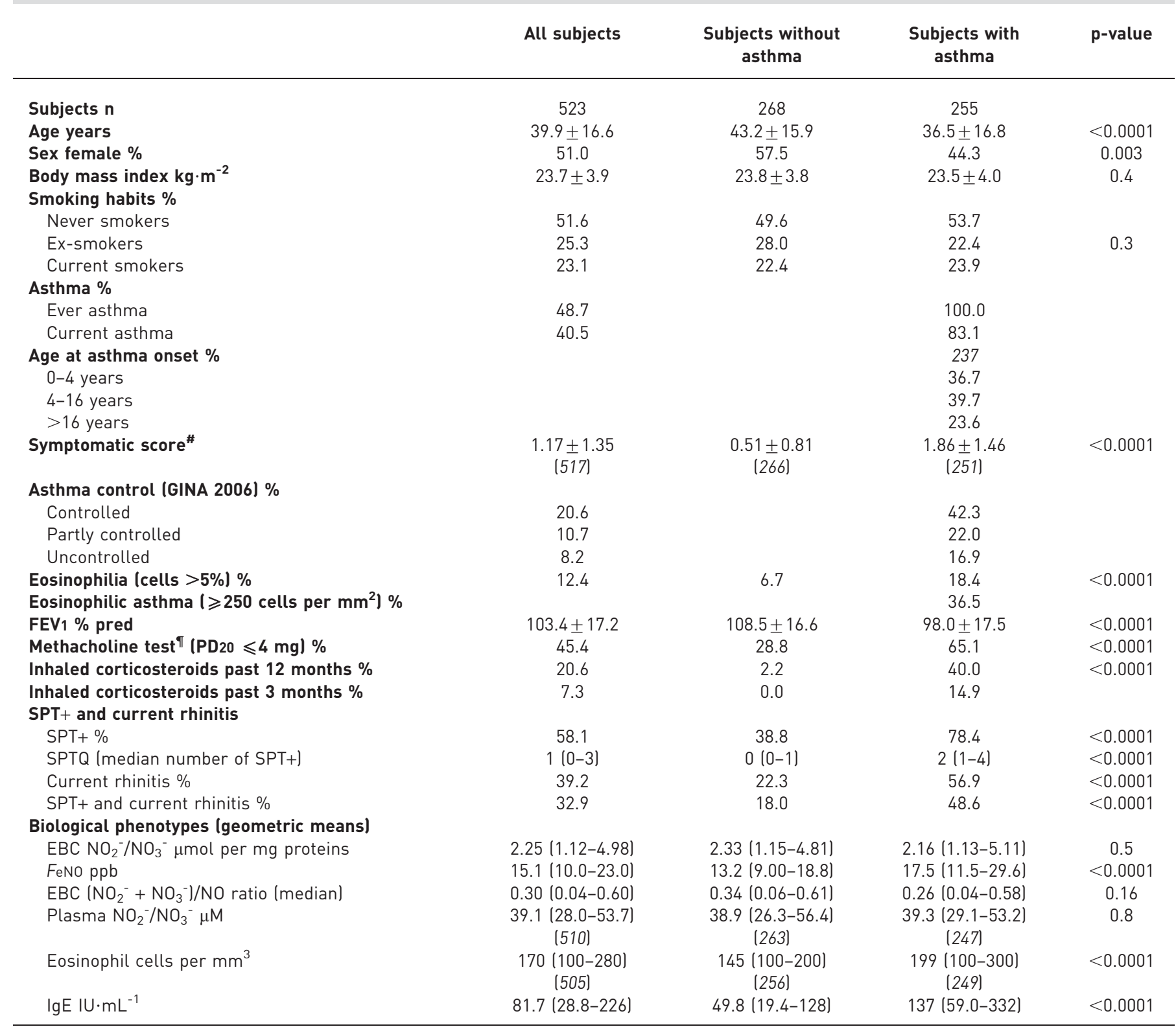

Data are presented as mean $\pm S D$, unless otherwise stated. Medians and geometric means are shown with interquartile ranges. Values of $n$ are present in italics when differing from total n. GINA: Global Initiative for Asthma; FEV1: forced expiratory volume in 1 s; PD20: provocative dose causing a $20 \%$ fall in FEV1; SPT+: positive skin prick test, i.e. a mean wheal diameter $\geqslant 3 \mathrm{~mm}$ than the negative control for at least one of 12 aeroallergens; SPTQ: quantitative SPT score; EBC: exhaled breath condensate; FeNO: exhaled nitric oxide fraction; Ig: immunoglobulin. \#: symptomatic score is based on the number of asthma symptoms (wheeze and breathlessness, woken with chest tightness, woken by attack of shortness of breath, attack of shortness of breath at rest, attack of shortness of breath after exercise); ${ }^{\top}$ : methacholine challenge test was not performed if baseline FEV1 $<80 \%$ pred.

\section{Results}

The characteristics of the 523 adults according to their asthma status are summarised in table 1. As expected, subjects with asthma had significantly higher eosinophilia, lower FEV1\% predicted, more often bronchial hyper-responsiveness (BHR), SPT+, and more often reported current rhinitis, than subjects without asthma. After adjustment for age, sex and smoking, the following associations between asthma and eosinophilia (OR 3.12, 95\% CI 1.72-5.66), FEV1 (mean \pm SD $107.7 \pm 10.5$ versus $97.5 \pm 11.0 \%$ pred), BHR (OR 4.18, 95\% CI 2.66-6.57), SPT+ (OR 5.07, 95\% CI 3.32-7.72) and current rhinitis (OR 4.62, 95\% CI 3.11-6.85) were confirmed (all p <0.0005). Eosinophil count, IgE and FeNO levels were significantly higher 
TABLE 2 Pairwise association of exhaled breath condensate (EBC) $\mathrm{NO}_{2}{ }^{-} / \mathrm{NO}_{3}{ }^{-}$, exhaled nitric oxide fraction (FeNO) levels and eosinophil count in all subjects, and according to allergic sensitisation

\begin{tabular}{|c|c|c|c|c|c|c|c|c|}
\hline & \multicolumn{4}{|c|}{$\begin{array}{l}\mathrm{EBC} \mathrm{NO}_{2}^{-} / \mathrm{NO}_{3}^{-} \text {level } \\
\mu \mathrm{mol} \text { per mg proteins }\end{array}$} & \multicolumn{4}{|c|}{ Feno level ppb ${ }^{\pi}$} \\
\hline & $\mathbf{n}$ & Estimate & SD & p-value & $\mathbf{n}$ & Estimate & SD & p-value \\
\hline \multicolumn{9}{|l|}{ All subjects } \\
\hline Eosinophil cells per $\mathrm{mm}^{3}$ & 492 & 0.14 & 0.09 & 0.10 & 505 & 0.25 & 0.04 & $<0.0001$ \\
\hline FeNO level ppb & 510 & 0.14 & 0.08 & 0.10 & & & & \\
\hline FeNo level ppb & 215 & -0.17 & 0.15 & 0.3 & & & & \\
\hline \multicolumn{9}{|l|}{ Sensitised subjects } \\
\hline Eosinophil cells per $\mathrm{mm}^{3}$ & 288 & 0.15 & 0.11 & 0.2 & 297 & 0.31 & 0.06 & $<0.0001$ \\
\hline FeNO level ppb & 295 & 0.21 & 0.10 & 0.04 & & & & \\
\hline
\end{tabular}

\#: adjusted for age, sex, smoking, ambient ozone concentration, asthma and centre; ${ }^{\natural}$ : adjusted for age, sex, smoking, height, asthma and centre (generalised estimating equation linear regression methods).

in subjects with asthma than in those without (all $\mathrm{p}<0.0001$ ). $\mathrm{EBC} \mathrm{NO}_{2}{ }^{-} / \mathrm{NO}_{3}{ }^{-}$level was unrelated to ICS use (data not shown, $\mathrm{p}=0.5$ ).

\section{Pairwise association between $\mathrm{EBC} \mathrm{NO}{ }_{2}^{-} / \mathrm{NO}_{3}{ }^{-}, \mathrm{FeNO}$ levels and blood eosinophil counts}

EBC $\mathrm{NO}_{2}{ }^{-} / \mathrm{NO}_{3}{ }^{-}$levels were unrelated to eosinophil counts, whereas FeNO levels were positively associated with eosinophils in all subjects, both in non-sensitised and sensitised subjects (table 2). In sensitised subjects, EBC $\mathrm{NO}_{2}{ }^{-} / \mathrm{NO}_{3}{ }^{-}$was positively associated with $\mathrm{FeNO}$ levels.

The median (range) FeNO value in the population was 15.6 (2.4-99.0) ppb. Stratification according to this median value showed positive and significant association between $\mathrm{EBC} \mathrm{NO}_{2}{ }^{-} / \mathrm{NO}_{3}{ }^{-}$level and allergic sensitisation in subjects above the median only (2.66 (2.06-3.43) versus $1.64(1.18-2.28) \mu \mathrm{mol}$ per $\mathrm{mg}$ proteins, $\mathrm{p}=0.01$, and $2.03(1.52-2.71)$ versus $1.76(1.30-2.38) \mu \mathrm{mol}$ per $\mathrm{mg}$ proteins, $\mathrm{p}=0.4$, in subjects above and below the median, respectively).

\section{Plasma and $\mathrm{EBC} \mathrm{NO}{ }_{2}^{-} / \mathrm{NO}_{3}{ }^{-}, \mathrm{FeNO}$ levels and asthma and asthma-related phenotypes}

Both plasma and $\mathrm{EBC} \mathrm{NO}_{2}{ }^{-} / \mathrm{NO}_{3}{ }^{-}$levels were unrelated to ever asthma, current asthma, symptomatic score, and asthma control (data not shown, all $\mathrm{p}>0.3$ ). Furthermore, plasma $\mathrm{NO}_{2}{ }^{-} / \mathrm{NO}_{3}{ }^{-}$level was unrelated to allergic sensitisation and current rhinitis.

Both plasma and $\mathrm{EBC} \mathrm{NO}{ }_{2}{ }^{-} / \mathrm{NO}_{3}{ }^{-}$levels were not related to eosinophilic asthma nor to age at asthma onset (table 3). As expected, a positive and significant association was observed between FeNO level and eosinophilic asthma (table 3), but no other significant association was observed.

\section{EBC NO${ }_{2}^{-} / \mathrm{NO}_{3}{ }^{-}$and $\mathrm{FeNO}$ levels, $\mathrm{NO}_{x} / \mathrm{NO}$ ratio and allergic sensitisation}

A positive association at borderline significance was observed between $\mathrm{EBC} \mathrm{NO}_{2}{ }^{-} / \mathrm{NO}_{3}{ }^{-}$level and SPT+ (table 4). In a model adjusted for covariates, including asthma, $\mathrm{EBC} \mathrm{NO}_{2}{ }^{-} / \mathrm{NO}_{3}{ }^{-}$level was positively and significantly associated with $\mathrm{SPT}+$, and a positive association at borderline significance was observed with current rhinitis. Furthermore, positive and gradual increases in $\mathrm{EBC} \mathrm{NO}_{2}{ }^{-} / \mathrm{NO}_{3}{ }^{-}$level were observed with quantitative SPT score (SPTQ) (fig. S1 in supplementary data), and when subjects were classified in the following groups: no SPT+, SPT+ only, and both SPT+ and current rhinitis (table 4 and fig. 2). The median (range) $\mathrm{EBC} \mathrm{NO}_{2}{ }^{-} / \mathrm{NO}_{3}{ }^{-}$value in our population was 2.35 (1.14-4.9) $\mu \mathrm{mol}$ per mg proteins (table 1). Stratification according to this median value showed positive and significant associations between subjects above the median value and 1) allergic sensitisation (OR 1.92, 95\% CI 1.25-2.97, $\mathrm{p}=0.003$ ), 2) current rhinitis (OR 1.52, 95\% CI 1.01-2.28, p=0.04), and 3) SPT+ only or both SPT+ and current rhinitis versus no SPT+ (OR 1.64, 95\% CI 1.01-2.66, p =0.04, and OR 2.16, 95\% CI 1.29-3.59, p =0.003, respectively) in GEE regression models with adjustement for age, sex, smoking, ambient ozone concentration, asthma and centre.

Similarly to EBC $\mathrm{NO}_{2}{ }^{-} / \mathrm{NO}_{3}{ }^{-}$, FeNO level was also positively related to allergic sensitisation expressed as SPT+ (table 4), and gradually increased with SPTQ (fig. S1), and with allergic sensitisation and current rhinitis. FeNO was also significantly and positively associated with current rhinitis. The associations between 
TABLE 3 Associations between exhaled nitric oxide fraction ( $F \mathrm{eNO}$ ), total $\mathrm{NO}_{2}{ }^{-} / \mathrm{NO}_{3}{ }^{-}$and ratio levels in exhaled breath condensate (EBC) with eosinophilic asthma and age at onset

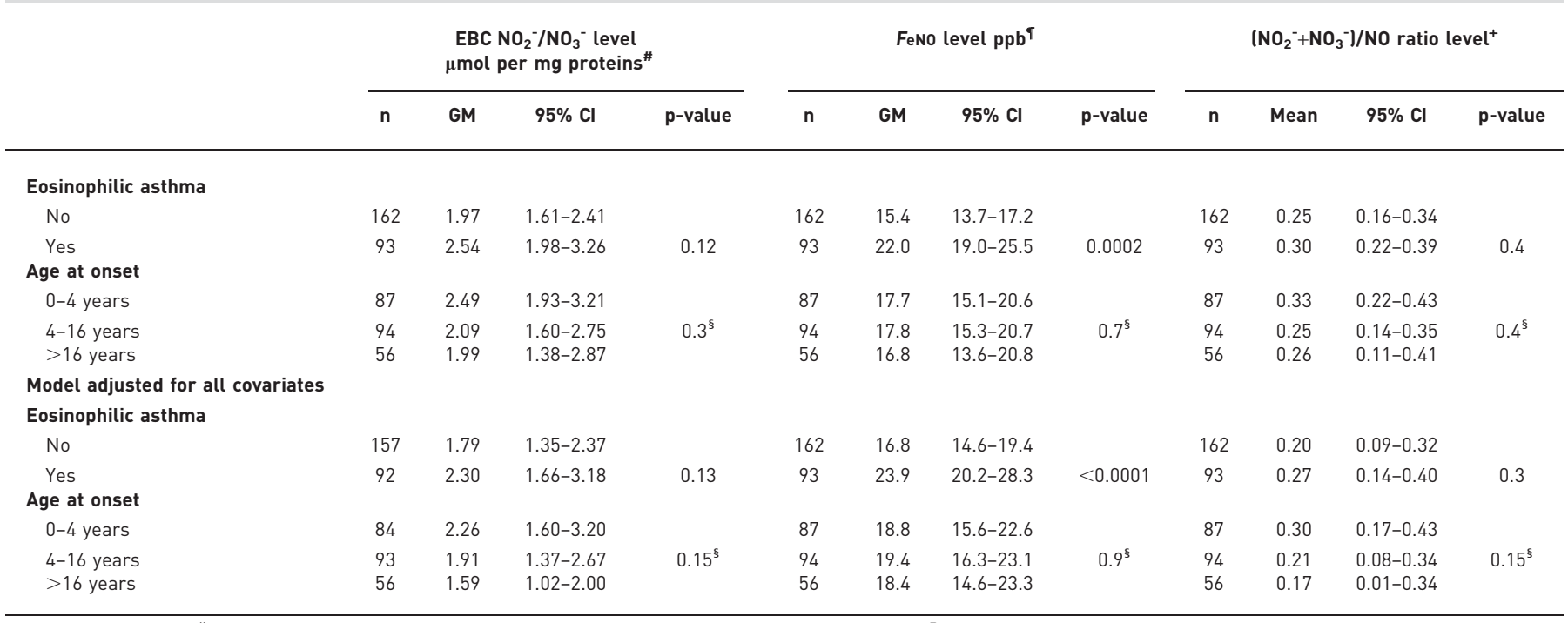

GM: geometric mean. ${ }^{\#}$ : adjusted for age, sex, smoking, ambient ozone concentration, asthma and centre; ${ }^{\bullet}$ : adjusted for age, sex, smoking, height, asthma and centre lgeneralised estimating equation regression methods); ${ }^{+}$: adjusted for age, sex, smoking, asthma and centre; ${ }^{\S}$ : $p$-value for trend.

FeNO levels and SPT+, and current rhinitis were confirmed when BMI instead of height was added as a covariate in the models (data not shown).

No significant association were observed between the $\left(\mathrm{NO}_{2}{ }^{-}+\mathrm{NO}_{3}{ }^{-}\right) / \mathrm{NO}$ ratio $\left(\mathrm{NO}_{\mathrm{x}} / \mathrm{NO}\right.$ ratio $)$ and SPT+, current rhinitis or both (table 4 and fig. 2). When analysing SPT+ to indoor, outdoor or mould allergens separately, $\mathrm{EBC} \mathrm{NO}_{2}{ }^{-} / \mathrm{NO}_{3}{ }^{-}$levels showed positive and significant associations with sensitisation to mould allergens, and FeNO levels were positively associated to indoor allergens (table 4).

\section{Discussion}

The present study conducted on a large sample of adults with a precise phenotypic characterisation shows, for the first time, the similarities and differences for the associations of both $F$ eNO and $\mathrm{EBC}^{-} \mathrm{NO}_{2}{ }^{-} / \mathrm{NO}_{3}{ }^{-}$ levels with asthma, allergic sensitisation and rhinitis. Results showed higher $\mathrm{EBC} \mathrm{NO}_{2}{ }^{-} / \mathrm{NO}_{3}{ }^{-}$and $\mathrm{FeNO}$ levels in subjects with allergic sensitisation, with current rhinitis, and in particular when both are present. Only FeNO levels were found to be higher with asthma. $\mathrm{EBC} \mathrm{NO}_{2}{ }^{-} / \mathrm{NO}_{3}{ }^{-}$and $\mathrm{FeNO}$ levels were positively associated in sensitised subjects only, and $\mathrm{EBC} \mathrm{NO}_{2}{ }^{-} / \mathrm{NO}_{3}{ }^{-}$levels were found to be associated with allergic sensitisation in subjects with higher FeNO levels only.

The selection of the 523 subjects included in the present analyses was driven first by the random availability of the FeNO measurements in three of the five participating centres [22], and secondly by the availability of the other variables of interest. Definition of asthma case is very precise in our study, since asthmatic cases were recruited in chest clinics, and a procedure was set up to include true asthmatics, leading to a very limited risk of false-positives. Prevalence of BHR, measured by a methacholine challenge test was quite high in subjects without asthma. A possible explanation is that some of the subjects without asthma are first degree relatives of asthma cases. Nevertheless, this result is consistent with the relatively considerable number of asymptomatic subjects with BHR reported in cross-sectional epidemiological studies, ranging from 19.3 to $62.4 \%$. Subjects included in the analyses had higher $\mathrm{EBC} \mathrm{NO}_{2}{ }^{-} / \mathrm{NO}_{3}{ }^{-}$and $\mathrm{FeNO}$ levels than nonselected subjects. Other limitations of the present study were those commonly related to cross-sectional analyses of the data.

We reported no association between $\mathrm{NO}_{2}{ }^{-} / \mathrm{NO}_{3}{ }^{-}$level measured in plasma and any disease phenotypes. We previously reported that plasma and $\mathrm{EBC} \mathrm{NO}_{2}{ }^{-} / \mathrm{NO}_{3}{ }^{-}$levels were not correlated [18]. The metabolism of $\mathrm{NO}$ is complex, and the production of $\mathrm{NO}_{2}{ }^{-} / \mathrm{NO}_{3}{ }^{-}$in plasma differs from that in $\mathrm{EBC}$ due to their compartmentalisation. In plasma $\mathrm{NO}_{2}{ }^{-} / \mathrm{NO}_{3}{ }^{-}$production derives from several sources, such as bacteria, enzymatic production and dietary sources [24]. In $\mathrm{EBC}$ ionised $\mathrm{NO}_{3}{ }^{-}$and $\mathrm{NO}_{2}{ }^{-}$(not volatile) may arise from NO after reaction with oxygen [25] or from activated immune cells present in the lining fluid of the lungs [26]. Overall, the specificities of the NO metabolism in plasma and in EBC may partly explain the lack of association with any clinical phenotypes in plasma. Our results are consistent with the hypotheses of 


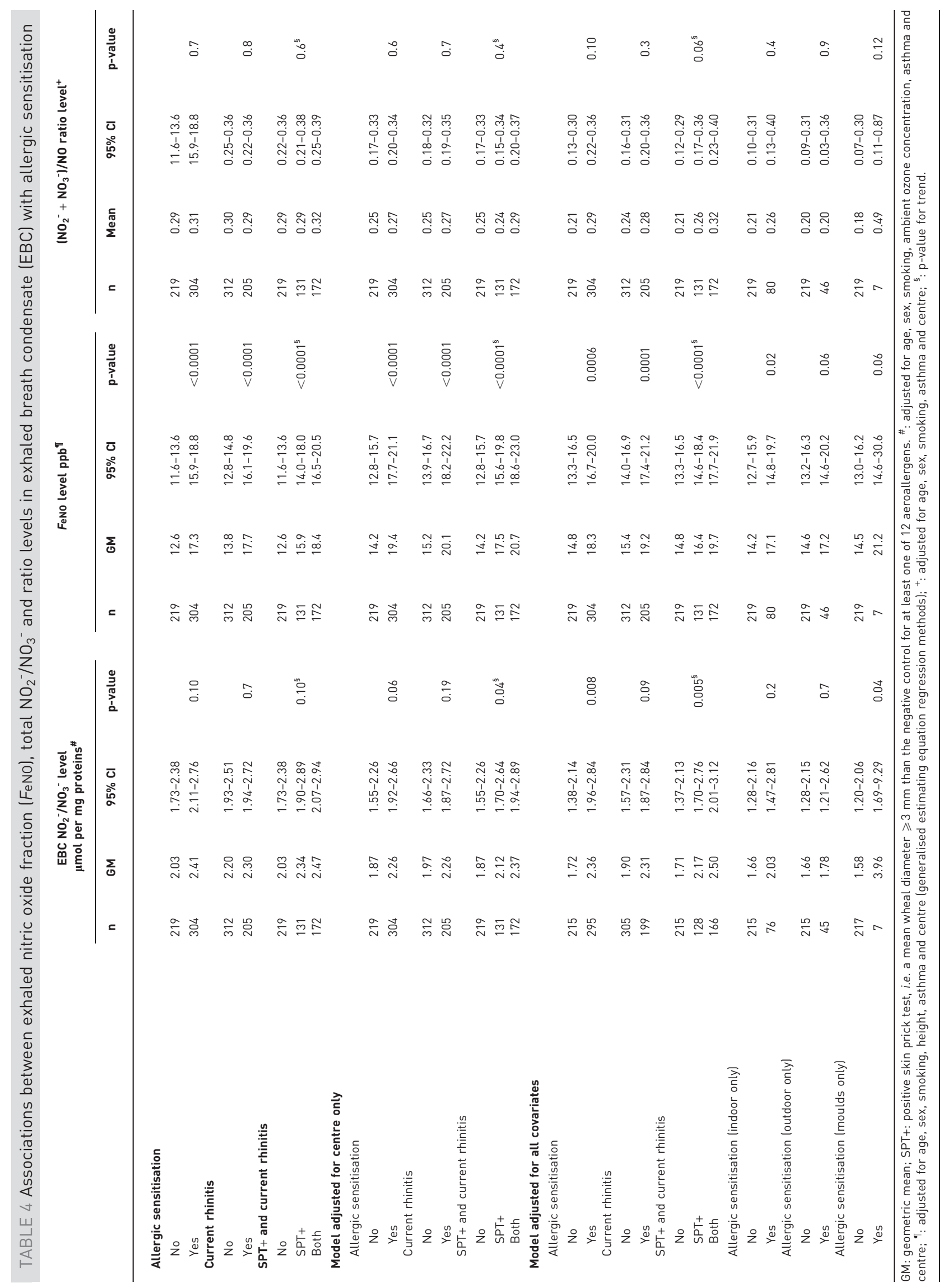




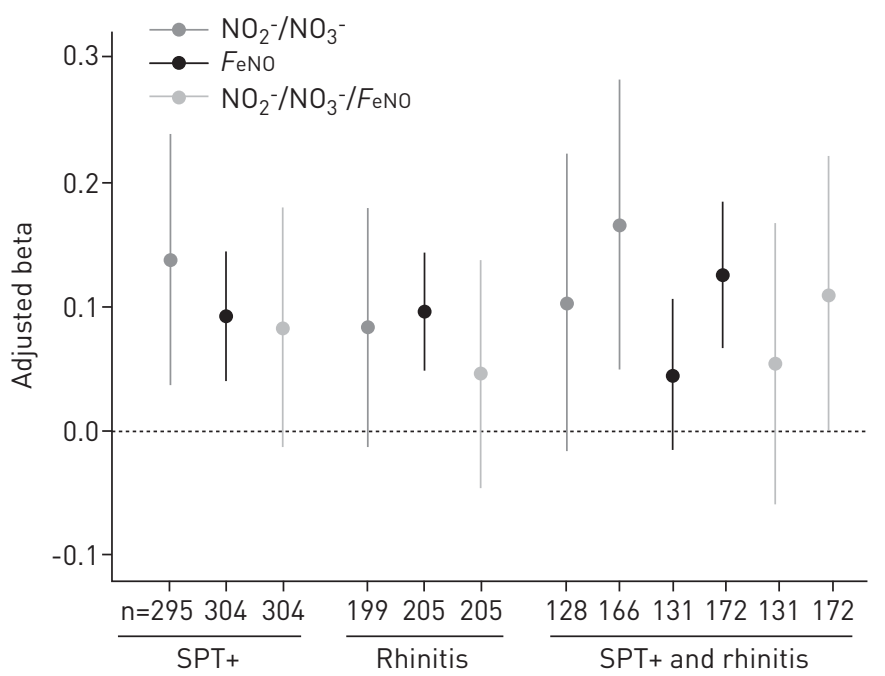

FIGURE 2 Associations between exhaled nitric oxide fraction ( FeNO), total $\mathrm{NO}_{2}{ }^{-} / \mathrm{NO}_{3}{ }^{-}$and $\left(\mathrm{NO}_{2}{ }^{-}+\mathrm{NO}_{3}{ }^{-}\right) / \mathrm{NO}$ ratio levels in exhaled breath condensate with allergic sensitisation, current rhinitis and both. Regression coefficients (beta) and 95\% confidence intervals for associations between FeNO, total $\mathrm{NO}_{2}{ }^{-} / \mathrm{NO}_{3}{ }^{-}$levels, $\left(\mathrm{NO}_{2}{ }^{-}+\mathrm{NO}_{3}{ }^{-}\right) / \mathrm{NO}$ ratio and allergic sensitisation, current rhinitis and both, estimated through generalised estimating equation linear regression methods, and adjusted for covariates: age, sex, smoking, ambient ozone concentration, asthma and centre for $\mathrm{NO}_{2}{ }^{-} / \mathrm{NO}_{3}{ }^{-}$level; age, sex, smoking, height, asthma and centre for FeNO level; age, sex, smoking, asthma and centre for $\left(\mathrm{NO}_{2}^{-}+\mathrm{NO}_{3}^{-}\right) / \mathrm{NO}$ ratio. SPT+: positive skin prick test, i.e. a mean wheal diameter $\geqslant 3 \mathrm{~mm}$ than the negative control for at least one of 12 aeroallergens.

Villanueva and GiUlivi [19], for whom the compartmentalised production of NO better explains its different functions and roles in pathophysiology.

No association was found between total $\mathrm{NO}_{2}{ }^{-} / \mathrm{NO}_{3}{ }^{-}$level in $\mathrm{EBC}$ and asthma phenotypes, as previously reported in other studies $[8,14]$. Contrary to our results, other studies have reported total $\mathrm{NO}_{2}{ }^{-} / \mathrm{NO}_{3}{ }^{-}$level in EBC to be elevated in subjects with asthma compared to healthy nonsmoking subjects [17], healthy nonatopic controls [5] or controls [9]. These conflicting results may be due to the very small number of subjects included in these studies, the various methodologies used for measuring $\mathrm{NO}_{2}{ }^{-}$and $\mathrm{NO}_{3}{ }^{-}$levels, the choice of the reference group for comparisons and other differences such as those related to phenotypes definition. Beside, information regarding allergic sensitisation was not available or subjects were defined as asthmatics if they had both asthma and allergy, suggesting that the increase in $\mathrm{NO}_{2}{ }^{-} / \mathrm{NO}_{3}{ }^{-}$level could be more related to allergy than to asthma. Furthermore, none of these previous studies have expressed the $\mathrm{NO}_{2}{ }^{-} / \mathrm{NO}_{3}{ }^{-}$level divided by the amount of proteins. As reported by GESSNER and WIRTZ [27], the measurement of total protein in EBC is important to confirm that protein and peptide markers are comparable between studies. They should always be performed in addition to specific markers investigated, and we previously found that $\mathrm{NO}_{2}{ }^{-} / \mathrm{NO}_{3}{ }^{-}$level in $\mathrm{EBC}$ was positively related to protein concentration in our study [28].

As reported in the literature [4, 29], positive associations between FeNO level and asthma, allergic sensitisation, and current rhinitis were found in this study. To our knowledge, our study reported for the first time similarities and differences for the associations of both FeNO and exhaled breath condensate $\mathrm{NO}_{2}{ }^{-} / \mathrm{NO}_{3}{ }^{-}$levels with asthma, allergic sensitisation and current rhinitis. We found positive associations between $\mathrm{EBC} \mathrm{NO}_{2}{ }^{-} / \mathrm{NO}_{3}{ }^{-}$and $\mathrm{FeNO}$ levels in sensitised subjects, and between $\mathrm{EBC} \mathrm{NO}_{2}{ }^{-} / \mathrm{NO}_{3}{ }^{-}$levels with allergic sensitisation in subjects with higher FeNO levels. Consistently, we found that both $\mathrm{EBC}^{-} \mathrm{NO}_{2}{ }^{-} / \mathrm{NO}_{3}{ }^{-}$ and FeNO levels increased with allergic sensitisation, with the number of SPT+, and that gradual relationships were observed between sensitised subjects only and those with both allergic sensitisation and rhinitis. An immediate practical utility could not be inferred from the results obtained in the framework of this epidemiological study, but taken together, our results suggest that $\mathrm{EBC} \mathrm{NO}_{2}{ }^{-} / \mathrm{NO}_{3}{ }^{-}$and $\mathrm{FeNO}$ levels may be considered as biological markers of intensity of allergic sensitisation and rhinitis. Longitudinal studies are also needed to better understand the role of these biomarkers, in line with the idea that part of the "allergic march" involves oxidative and nitrosative processes.

By considering together EBC $\mathrm{NO}_{2}{ }^{-} / \mathrm{NO}_{3}{ }^{-}$and $\mathrm{FeNO}$ levels rather than each alone, our results provided complementary interesting information. To go further, we also studied the association between the $\mathrm{NO}_{\mathrm{x}}$ $\left(\mathrm{NO}_{2}{ }^{-}+\mathrm{NO}_{3}{ }^{-}\right) / \mathrm{NO}$ ratio and allergic sensitisation. Unfortunately, this ratio was not more informative than 
considering the measurement of $\mathrm{EBC} \mathrm{NO}_{2}{ }^{-} / \mathrm{NO}_{3}{ }^{-}$alone. Contrary to our results, a ratio also including $S$-nitrosothiols, $\left(\mathrm{NO}_{2}{ }^{-}+\mathrm{NO}_{3}{ }^{-}+S\right.$-nitrosothiols $) / \mathrm{NO}$, was found to better evaluate inflammation in a case-control study on asthma [13] than the measurement of each oxide of nitrogen alone. This discrepancy in the results may be partly explained by the lack of measurement of $S$-nitrosothiols in our study, by the fact that we studied allergic sensitisation rather than inflammation, and/or by differences in study designs.

Overall, even if our results need to be replicated, they may suggest a role of the nitrate-nitrite-NO pathway in allergic sensitisation. We suggest that exposure to allergens results in uptake and proceeding by dendritic cells inducing the development of Th2 cells in sensitised individuals. Recent evidence indicates that airway epithelium also plays an important role in the allergic airway response by the release of interleukin (IL)-25, IL-33 and thymic stromal lymphopoietin (TSLP) which activate dendritic cells, basophils, eosinophils and Th2 cells [30, 31]. TSLP, IL-25 and IL-33 promote eosinophilia in airway mucosa by inducing IL-5 production. Eosinophilic airway inflammation may increase the NO concentration and subsequently produces the formation of $\mathrm{NO}_{2}^{-}, \mathrm{NO}_{3}{ }^{-}$and reactive nitrogen species in EBC.

The results reported in this study highlight the complexity of NO metabolism. Initially considered completely inert, it is now apparent that nitrate and nitrite are physiologically recycled in blood and tissues to form NO and other bioactive nitrogen oxides [2]. They may be viewed as storage pools for NO-like bioactivity, thereby complementing the NO synthase-dependent pathway. NO and related compounds are produced by a wide variety of residential and inflammatory cells in the respiratory tract [32]. In response to allergens, both dendritic cells and airway epithelial cells are stimulated, and release various cytokines which activate dendritic cells, basophils, mast cells, eosinophils and Th2 cells, leading to eosinophil activation and proliferation [33]. We previously reported that FeNO level was positively associated with blood eosinophil counts [18], and there is in vitro evidence that human blood eosinophils produce NO and participate in the regulation of the NO pool in pulmonary tissues $[34,35]$. Moreover, NO modulates the Th1/Th2 balance by favouring Th2 response and IL-5 production and thus recruiting eosinophils into the airways. Nevertheless, even if $\mathrm{EBC} \mathrm{NO}_{2}{ }^{-} / \mathrm{NO}_{3}{ }^{-}$level can be viewed as a potential biological marker of allergy in our study, its specific role remains unknown, and mechanistic studies are required. As suggested through the results of the present study, and as reported by ERZURUM and GASTON [36], the complexity of the nitrate-nitrite-NO pathway provides evidence that more targeted biological markers are needed for inclusion in a global scheme to help us to identify a type of response or phenotype for a given patient, requiring the integration of multiple factors in a system biology approach. Further studies are also warranted to better investigate the associations we observed in this epidemiological study, and the potential for a practical utility of our findings.

In conclusion, we report for the first time in a large epidemiological study that both total $\mathrm{NO}_{2}{ }^{-} / \mathrm{NO}_{3}{ }^{-}$and FeNO levels in EBC are associated with allergic sensitisation and rhinitis. The role of the nitrate-nitrite-NO pathway in the "allergic march" need to be further investigated in longitudinal studies. However, contrary to what has been shown with FeNO, we did not find an association of this biomarker with clinical phenotypes of asthma. Studying both $\mathrm{FeNO}$ and $\mathrm{EBC} \mathrm{NO}{ }^{-} / \mathrm{NO}_{3}{ }^{-}$may help to disentangle the associations between $\mathrm{NO}$ metabolism and asthma, allergic sensitisation and rhinitis.

\section{Acknowledgements}

The authors thank all those who participated in the study and in the various aspects of the examinations, and all those who supervised the study in all centres. The authors are grateful to the three CIC-Inserm units of Necker, Grenoble and Marseille that supported the study and where subjects were examined. They are also grateful to the three biobanks in Lille (CIC-Inserm), Evry (Centre National de Genotypage) and Annemasse (Etablissement francais du sang) where biological samples are stored. They are indebted to all the individuals who participated, without whom the study would not have been possible.

The members of the EGEA cooperative group are as follows. Coordination: V. Siroux (epidemiology, principal investigator since 2013), F. Demenais (genetics), I. Pin (clinical aspects), R. Nadif (biology) and F. Kauffmann (principal investigator 1992-2012). Respiratory epidemiology: Inserm U 700, Paris: M. Korobaeff (Egea1) and F. Neukirch (Egea1); Inserm U 707, Paris: I. Annesi-Maesano (Egea1-2); Inserm CESP/U 1018, Villejuif: F. Kauffmann, N. Le Moual, R. Nadif, M.P. Oryszczyn (Egea1-2) and R. Varraso; Inserm U 823, Grenoble: V. Siroux. Genetics: Inserm U 393, Paris: J. Feingold; Inserm U 946, Paris: E. Bouzigon, F. Demenais and M.H. Dizier; CNG, Evry: I. Gut (now CNAG, Barcelona, Spain) and M. Lathrop (now University McGill, Montreal, QC, Canada). Clinical centres: Grenoble: I. Pin and C. Pison; Lyon: D. Ecochard (Egea1), F. Gormand and Y. Pacheco; Marseille: D. Charpin (Egea1) and D. Vervloet (Egea1-2); Montpellier: J. Bousquet; Paris Cochin: A. Lockhart (Egea1) and R. Matran (now in Lille); Paris Necker: E. Paty (Egea1-2) and P. Scheinmann (Egea1-2); Paris-Trousseau: A. Grimfeld (Egea1-2) and J. Just. Data and quality management: Inserm ex-U155 (Egea1): J Hochez; Inserm CESP/U 1018, Villejuif: N. Le Moual; Inserm ex-U780: C. Ravault (Egea1-2); Inserm ex-U794: N. Chateigner (Egea1-2); Grenoble: J. Quentin-Ferran (Egea1-2).

\section{References}

1 Lundberg JO, Weitzberg E. The biological role of nitrate and nitrite: the times they are a-changin'. Nitric Oxide 2010; 22: 61-63. 
2 Lundberg JO, Weitzberg E, Gladwin MT. The nitrate-nitrite-nitric oxide pathway in physiology and therapeutics. Nat Rev Drug Discov 2008; 7: 156-167.

Szefler SJ, Wenzel S, Brown R, et al. Asthma outcomes: biomarkers. J Allergy Clin Immunol 2012; 129: S9-S23.

4 Dweik RA, Boggs PB, Erzurum SC, et al. An official ATS clinical practice guideline: interpretation of exhaled nitric oxide levels (FENO) for clinical applications. Am J Respir Crit Care Med 2011; 184: 602-615.

5 Chérot-Kornobis N, Hulo S, Edmé JL, et al. Analysis of nitrogen oxides (NOx) in the exhaled breath condensate (EBC) of subjects with asthma as a complement to exhaled nitric oxide (FeNO) measurements: a cross-sectional study. BMC Res Notes 2011; 4: 202.

6 Chladkova J, Krcmova I, Chladek J, et al. Validation of nitrite and nitrate measurements in exhaled breath condensate. Respiration 2006; 73: 173-179.

7 Corradi M, Pesci A, Casana R, et al. Nitrate in exhaled breath condensate of patients with different airway diseases. Nitric Oxide 2003; 8: 26-30.

8 Dressel H, Müller F, Fischer R, et al. Independent information of nonspecific biomarkers in exhaled breath condensate. Respiration 2010; 80: 401-409.

9 Ganas K, Loukides S, Papatheodorou G, et al. Total nitrite/nitrate in expired breath condensate of patients with asthma. Respir Med 2001; 95: 649-654.

10 Dweik RA, Comhair SA, Gaston B, et al. NO chemical events in the human airway during the immediate and late antigen-induced asthmatic response. Proc Natl Acad Sci USA 2001; 98: 2622-2627.

11 Gratziou C, Rovina N, Makris M, et al. Breath markers of oxidative stress and airway inflammation in seasonal allergic rhinitis. Int J Immunopathol Pharmacol 2008; 21: 949-957.

12 Malinovschi A, Pizzimenti S, Sciascia S, et al. Exhaled breath condensate nitrates, but not nitrites or FENO, relate to asthma control. Respir Med 2011; 105: 1007-1013.

13 Nguyen TA, Woo-Park J, Hess M, et al. Assaying all of the nitrogen oxides in breath modifies the interpretation of exhaled nitric oxide. Vascul Pharmacol 2005; 43: 379-384.

14 Ojoo JC, Mulrennan SA, Kastelik JA, et al. Exhaled breath condensate $\mathrm{pH}$ and exhaled nitric oxide in allergic asthma and in cystic fibrosis. Thorax 2005; 60: 22-26.

15 Rihák V, Zatloukal P, Chládková J, et al. Nitrite in exhaled breath condensate as a marker of nitrossative stress in the airways of patients with asthma, COPD, and idiopathic pulmonary fibrosis. J Clin Lab Anal 2010; 24: 317-322.

16 Robroeks CMHHT, Van de Kant KDG, Jöbsis Q, et al. Exhaled nitric oxide and biomarkers in exhaled breath condensate indicate the presence, severity and control of childhood asthma. Clin Exp Allergy 2007; 37: 1303-1311.

17 Ueno T, Kataoka M, Hirano A, et al. Inflammatory markers in exhaled breath condensate from patients with asthma. Respirology 2008; 13: 654-663.

18 Bouzigon E, Monier F, Boussaha M. Associations between nitric oxide synthase genes and exhaled NO-related phenotypes according to asthma status. PloS One 2012; 7: e36672.

19 Villanueva C, Giulivi C. Subcellular and cellular locations of nitric oxide synthase isoforms as determinants of health and disease. Free Radic Biol Med 2010; 49: 307-316.

20 Kauffmann F, Dizier MH. EGEA (Epidemiological study on the Genetics and Environment of Asthma, bronchial hyperresponsiveness and atopy)-design issues. EGEA Co-operative Group. Clin Exp Allergy 1995; 25: Suppl. 2, 19-22.

21 Kauffmann F, Dizier MH, Pin I, et al. Epidemiological study of the genetics and environment of asthma, bronchial hyperresponsiveness, and atopy: phenotype issues. Am J Respir Crit Care Med 1997; 156: S123-S129.

22 Nadif R, Matran R, Maccario J, et al. Passive and active smoking and exhaled nitric oxide levels according to asthma and atopy in adults. Ann Allergy Asthma Immunol 2010; 104: 385-393.

23 Rava M, Varraso R, Decoster B, et al. Plasma and exhaled breath condensate nitrite-nitrate level in relation to environmental exposures in adults in the EGEA study. Nitric Oxide 2012; 27: 169-175.

24 Lundberg JO, Weitzberg E. NO-synthase independent NO generation in mammals. Biochem Biophys Res Commun 2010; 396: 39-45.

25 Hunt J. Exhaled breath condensate: an overview. Immunol Allergy Clin North Am 2007; 27: 587-596.

26 Fitzpatrick AM, Brown LAS, Holguin F, et al. Levels of nitric oxide oxidation products are increased in the epithelial lining fluid of children with persistent asthma. J Allergy Clin Immunol 2009; 124: 990-996.

27 Gessner C, Wirtz H. Interleukins and other proteins. In: Horvath I, de Jongste JC, eds. Exhaled Biomarkers. Eur Respir Monogr 2010; 49: 217-230.

28 Nadif R, Decoster B, Huyvaert H, et al. Total nitrate/nitrite levels in plasma and exhaled breath condensate: associations with age and smoking according to asthma among 1159 adults from the EGEA study. Am J Respir Crit Care Med 2010; 181: A3109.

29 ATS Workshop Proceedings: exhaled nitric oxide and nitric oxide oxidative metabolism in exhaled breath condensate: executive summary. Am J Respir Crit Care Med 2006; 173: 811-813.

30 Nadif R, Zerimech F, Bouzigon E, et al. The role of eosinophils and basophils in allergic diseases considering genetic findings. Curr Opin Allergy Clin Immunol 2013; 13: 507-513.

31 Diamant Z, Boot JD, Mantzouranis E, et al. Biomarkers in asthma and allergic rhinitis. Pulm Pharmacol Ther 2010; 23: $468-481$.

32 Sugiura H, Ichinose M. Nitrative stress in inflammatory lung diseases. Nitric Oxide 2011; 25: 138-144.

33 Blanchard C, Rothenberg ME. Biology of the eosinophil. Adv Immunol 2009; 101: 81-121.

34 Del Pozo V, De Arruda-Chaves E, De Andrés B, et al. Eosinophils transcribe and translate messenger RNA for inducible nitric oxide synthase. J Immunol 1997; 158: 859-864.

35 Iijima H, Duguet A, Eum SY, et al. Nitric oxide and protein nitration are eosinophil dependent in allergenchallenged mice. Am J Respir Crit Care Med 2001; 163: 1233-1240.

36 Erzurum SC, Gaston BM. Biomarkers in asthma: a real hope to better manage asthma. Clin Chest Med 2012; 33: $459-471$. 